International Journal of Current Advanced Research

ISSN: O: 2319-6475, ISSN: P: 2319 - 6505, Impact Factor: SJIF: 5.995

Available Online at www.journalijcar.org

Volume 6; Issue 5; May 2017; Page No. 3645-3651

DOI: http://dx.doi.org/10.24327/ijcar.2017.3651.0338

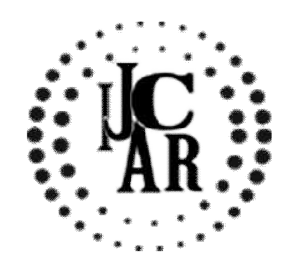

Case Report

\title{
ROLE OF CYTOKINES IN INFLAMMATORY DISEASES
}

\author{
Valli B and M.Sankari*
}

Saveetha University

\section{A R T I C L E I N F O}

\section{Article History:}

Received $20^{\text {th }}$ February, 2017

Received in revised form $4^{\text {th }}$ March, 2017

Accepted $15^{\text {th }}$ April, 2017

Published online $28^{\text {th }}$ May, 2017

\section{Key words:}

Cytokines, Inflammatory Disease, Arthritis

\begin{abstract}
A B S T T R A C T
Cytokines are small secreted proteins released by cells have a specific effect on the interactions and communications between cells. Cytokine is a general name; other names are lymphokine, monokine, chemokine, and interleukin. Cytokines may act on the cells that secrete them), on nearby cells, or in some instances on distant cells. There are both proinflammatory cytokines and anti-inflammatory cytokines. There is significant evidence showing that certain cytokines/chemokines are involved in not only the initiation but also the persistence of pathologic pain by directly activating nociceptive sensory neurons.
\end{abstract}

Copyright $\bigcirc 2017$ Valli B and M.Sankari. This is an open access article distributed under the Creative Commons Attribution License, which permits unrestricted use, distribution, and reproduction in any medium, provided the original work is properly cited.

\section{INTRODUCTION}

\section{Cytokines}

Cytokines are small molecules secreted by cells of the immune system that serve to regulate various other components of the immune system, and they play a crucial role in health and disease ${ }^{[1,2]}$

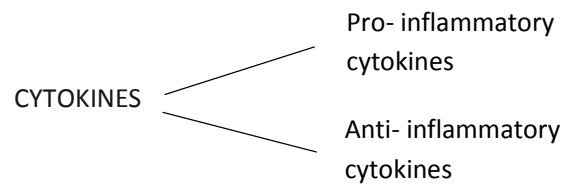

Types of Cytokines

\begin{tabular}{cc}
\hline Pro-inflammatory cytokines & Anti- inflammatory cytokines \\
\hline Interleukin- 1 & Interleukin-4 \\
Tumour necrosis factor & Interleukin- 13 \\
Gamma interferon (IFN-gamma) & Interleukin -10 \\
Interleukin-2 & Alpha interferon (IFN- Alpha) \\
Interleukin-18 & Transforming growth factor - beta \\
granulocyte-macrophage colony & \\
stimulating factor & \\
\hline
\end{tabular}

Alzheimer's Disease- Alzheimer's disease is a very common neurological degenerative disorder. It is the main cause for dementia in elderly people. Brain inflammation is a pathological hallmark of Alzheimer's disease ${ }^{[3]}$.

Pathogenesis of Alzheimer's Disease- Microglia and astrocytes surrounding $A \beta$ neuritic plaques secretes cytokine class of inflammatory mediators which gets increased in Inflammatory states and it functions to regulate intensity and duration of immune response ${ }^{[4]}$.

*Corresponding author: M.Sankari

Saveetha University
IL-1 group of cytokines is further divided into IL-1 alpha and IL-1 beta which triggers cell activation upon binding with specific membrane receptors. Here IL-1ra which is a glycosylated secretory protein of $23 \mathrm{kDa}$ counteracts IL-1.

\section{Actions of Il-1ß in Other Inflammatory Diseases}

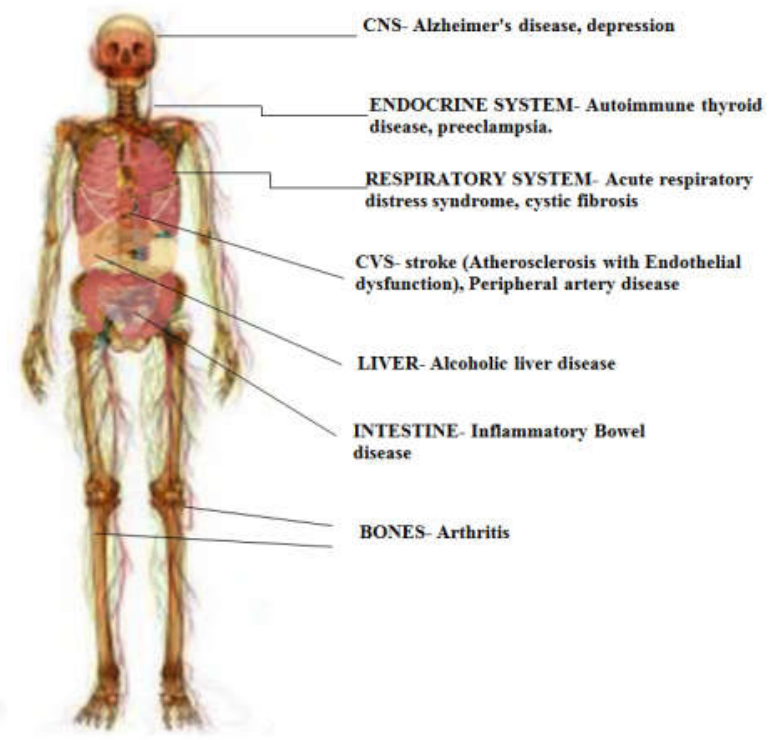

Role of IL-1 $\beta$

IL-1 is the initiator of immune response and IL-beta is found in elevated levels in CSF and brain parenchyma within early hours after brain injury ${ }^{[5,6]}$. IL-1 causes the onset and development of cellular and inflammatory cascade. IL-1 in the astrocytes induces IL-6 action and stimulates iNOS activity. Additionally IL-1 enhances neuronal acetylcholinesterase 
activity and induces the production of MCSF and microglial activation.

\section{Depression}

Major depressive disorder (MDD) is a ver common psychiatric illness and it is the main cause of disability worldwide $^{[7,8]}$.

\section{Symptoms}

\section{Biological Symptoms}

- $\quad$ Disturbed sleep with early morning wakening

- Loss of appetite

- Diurnal mood variation and

- Reduced libido.

\section{Cognitive Symptoms}

- Hopelessness

- Helplessness

- Worthlessness

- Poor concentration

- low-self esteem

- Guilt and

- $\quad$ Suicidal ideation.

\section{Pathogenesis of Depression}

Innate immune mechanism plays an integral role in depression which determines the type of $\mathrm{T}$ helper cells involved whether Th1 or Th 2 cells. In Th1 type of response the macrophages releases pro-inflammatory cytokines IFNgamma, TNF-alpha, Interleukin-1,2 by the recognition of pathogen, tissue damage or destruction with the help of Tolllike receptors ${ }^{[9,10]}$. These TLRs activates nuclear factor kappa $\mathrm{B}$ which in turn induces the innate inflammatory response by releasing pro-inflammatory cytokines like IL-1, IL-2, IL-6, TNF-Alpha ${ }^{[9,10,11]}$.

Pro-inflammatory cytokines creates a communication peripheral and central immune response. Pro-inflammatory cytokines accesses brain through leaky regions of $\mathrm{BBB}$, active transport across the $\mathrm{BBB}$, a neural pathway involving afferent nerve fibers such as the sensory vagus which relay information through the nucleus tractus solitarius, a humoral pathway, involving volume diffusion from circumventricular organs across the $\mathrm{BBB}^{[11,12,13]}$.

Sometimes BBB can be impaired in brain which allows extravasation of leukocyte and up-regulation of intracellular adhesion molecules.

\section{Auto-Immune Thyroid Disease}

Autoimmune diseases are a group of heterogeneous disorders which are identified by abnormal lymphocytic activation directed against self-tissue ${ }^{[14,15]}$. Autoimmune thyroid diseases (AITD) are a set of very common organ-specific autoimmune disorders, among which Hashimoto's thyroiditis (HT) and Graves' disease (GD) are two of the most common clinical forms.

\section{Role of Il-1 in Aitd}

$\mathrm{T}$ helper cells produces $\mathrm{Th}$ cells through TCR engagement and STAT signalling which is caused by IFN- $\gamma$ binding to its cognate receptor. Phosphorylated STAT4 signalling induces transcription factor-beta to help in differentiation of Th cells into Th1 cells and Th2 cells by transactivating IFN- $\gamma$ and also the specific subunit of IL-12R $\beta 2$, the receptor for IL-12. Now cell responds to IL-12 produced by the activated macrophages and DCs due to expression of $12 \mathrm{R} \beta 2$.

APCs produced by macrophages and DC, create a link between innate and acquired immune response, which in turn produces pro-inflammatory cytokines. Pro-inflammatory cytokines like TNF-Alpha and IL-1 $\beta$ induce adaptive immune response. DCs helps IL-12 to also induce adaptive immune response.

IL-1 $\beta$ has pleotropic effects which induces Cell signalling, migration, and cytokine production, and influence $\mathrm{T}$ cell differentiation differently under different conditions ${ }^{[16,17,18]}$

And facilitating the expansion of Teff which breaks peripheral tolerance causing auto-immune diseases like RA. IL-1 $\beta$ helps in the generation of IL-17 which secretes $\mathrm{T}$ helper cells in human. IL-23 along with IL-1 $\beta$ develops and maintains pathogenic Th17 cells which through several immune mechanisms by other inflammatory mediators lead to Graves' disease.

\section{Pre-Eclampsia}

Preeclampsia is considered to be a pregnancy-specific syndrome, identified by the new onset hypertension and proteinuria after 20th week of gestation. Preeclampsia occurs in almost $5 \%-7 \%$ of all pregnancies in the world, which is a main cause of the maternal and foetal mortality and morbidity ${ }^{[21]}$.

\section{Pathogenesis of Preeclampsia}

Serum inflammatory cytokines were found to be raised in pregnant patients with preeclampsia rather than normal pregnant patients. Inflammatory cytokines like IL- $1 \beta$, IFNgamma, IL-2, IL-6 causesharmful Th1 immunity, threatening pregnancy by generating cytotoxic factors that injured maternal endothelium, altered steroid hormones biosynthesisand also affected other factors which were implicated in trophoblast invasion and maternal spiral artery remodelling ${ }^{[22,23]}$. Cytokine gene regulates the production of inflammatory cytokines, therefore, the cytokines gene polymorphism plays a main role in the development of Preeclampsia.

IL-1 $\beta$ is a pro-inflammatory cytokine, belongs to the IL-1 system, has an important role in mammalian reproduction. It was reported that IL-1 $\beta$ was being implicated in the pathogenesis of preeclampsia ${ }^{[24]}$. Many researchers found that the plasma level of IL-1 $\beta$ was raised in preeclamptic women $^{[25-28]}$. And the elevated placental expression of IL-1 $\beta$ was also observed in several researches ${ }^{[26,29]}$.

\section{Diabetes Mellitus}

Diabetes mellitus is a group of endocrine diseaseidentified by hyperglycaemia due to lack of insulin or disruptions in insulin signalling. The very common forms of diabetes are type 1 and type 2 diabetes mellitus. Type 1 diabetes mellitus is an autoimmune disease which results in an insulin deficiency, while type 2 diabetes mellitus is determined by peripheral insulin resistance frequently in combination with a dysfunctional insulin production ${ }^{[30]}$. 


\section{Pathogenesis of DM}

Type 2 diabetes is associated with chronic activation of the innate immune system ${ }^{[31-33]}$. The increased number of isletrelated macrophages and elevated expression of interleukin (IL)- $1 \mathrm{~b}$ was reported in the pancreatic islets from patients with $\mathrm{T} 2 \mathrm{D}^{[34,35]}$. Elevated islet IL-1b levels was reported following chronic exposure of human islets to increased glucose,fatty acids, or leptin-3 factors whiich are closely related with $\mathrm{T} 2 \mathrm{D}^{[36,37,38]}$. Moreover, it was recently found that biosynthetic amyloid formation in human islets lead to b-cell dysfunction and death through induction of Fas upregulation and activation of the Fas-mediated apoptotic pathway started by caspase- 8 , which closely correlates with elevated islet IL$1 \mathrm{~b}$ level ${ }^{[39,40]}$. These studies provided evidence that amyloidinduced Fas upregulation is likely mediated by IL-1b. Along with these findings, Westwell-Roper et al. ${ }^{[41]}$ have reported bcell dysfunction associated with increased islet IL-1b expression in high fat-fed transgenic mice with islet amyloid formation. These findings helpsin local IL-1b production, likely created by multiple factors during prediabetic state and/or early stages of T2D, may play a key role in b-cell failure in T2D.

\section{Acute Respiratory Distress Syndrome}

The initial acute phase ofARDS is determined by the sudden onset of dyspnea, hypoxemia,respiratory failure, and bilateral infiltrates on chest radio graph which are consistent with pulmonary edema ${ }^{[42]}$. The sudden onset of respiratory failure usually needs mechanical ventilation.

\section{Pathogenesis And Role of Cytokines In Ards}

The inflammatory response in ARDS is started, amplified, and modulated by a complex network of cytokines and other proinflammatory molecules cytokineswhich are produced different cells in the lungs, including fibroblasts, epithelial cells, and inflammatory cells ${ }^{[43]}$. For (e.g.), tumor necrosis factor (TNF)-a and IL-1 are early response cytokines which are produced mostly by monocytes and macrophages as a result of direct or indirect insult to the lung such as endotoxin or other microbial products ${ }^{[44]}$. TNF-a and IL-1 acts on other cells, including macrophages, endothelial cells, fibroblasts, and epithelial cells to stimulate production of other cytokines, such as the neutrophil chemotactic factor IL-8. Increased concentrations of IL-8 are present in the alveolar space of patients with $\operatorname{ARDS}^{[45]}$.

Nuclear factor kappa-B (NFkB), which is a transcription factor that controls the expression of ICAM-1, IL-1b, IL-6, IL- 8, and TNF-a ${ }^{[46,47]}$. Activation of NFkB, allows the localisation to the nucleus and alter transcription. This nuclear localization of $\mathrm{NFkB}$ is a key proximal activation signal in the initiation, amplification and maintenance of the proinflammatory cytokine cascade in $\operatorname{ARDS}^{[47]}$.

\section{Cytsic Fibrosis}

Airway disease like cystic fibrosis (CF) is determined by a continuous cycle of chronic infection and inflammation which is dominated by a neutrophilic infiltrate. This kind of inflammation is determined by an elevated production of proinflammatory cytokines in the lung. This airway inflammation in cystic fibrosis is related with raised production of proinflammatory cytokines in the lung. Airway epithelial cells, macrophages, and neutrophils are capable of producing cytokines.

\section{Pathogenesis of Cystic Fibrosis}

The inflammatory response happening in cystic fibrosis lung is due to the complex balance prevailing between proinflammatory and anti- inflammatory mediators. The epithelial lining fluid of cystic fibrosis patients when compared to healthy controls was found to have reduced levels of antiinflammatory cytokine IL-10 ${ }^{[48]}$, which prevents the production of TNFa, IL-1 $\beta$, IL- 6 , and IL- 8 by macrophages $^{[49,50]}$. There are two more anti-inflammatory cytokines namely IRAP and TNFsR. Macrophages produce IRAP due to an inflammatory stimulus ${ }^{[51]}$ and it is a specific antagonist to IL-1a and IL-1 $\beta$. The pathogenesis of bone resorption and prevention of bone formation is mostly promoted due to the pro-inflammatory cytokines, especially TNFa and IL- $1 \beta^{[52,53,54]}$.

\section{Atherothrombosis- Stroke}

Stroke is a very common neurological disorder which is the second main cause of death worldwide ${ }^{[55]}$. It is determined that by 2030, there would be almost 12 million stroke deaths, 70 million stroke survivors, and also more than 200 million disability-adjusted life-years lost from stroke each year.

\section{Pathogenesis of Stroke AND Role of Cytokines}

Interleukin-1 (IL1), is a highly active pro-inflammatory cytokine, which acts as a main regulator of inflammatory process and it triggers a cascade of inflammatory mediators by the activation of the IL1 receptor ${ }^{[56]}$. There are two associated but individual IL1 genes, IL1A and IL1B, which encodes for IL $1 \alpha$ and IL1 $\beta$, respectively. Experimental results show abnormal levels ofIL1 $\alpha$ or IL1 $\beta$ which leads to inflammatory diseases. IL1 is found to involve in the acute and chronic neurodegenerative brain disorders, including ischemic stroke, Alzheimer's disease and Parkinson's disease, even though the cytokine is thought to be involved in the recovery of neurological functions ${ }^{[56,57]}$.

IL6 is a main early mediator of the inflammatory and overall immune response and plays an important role in the development of pathological conditions ${ }^{[58,59]}$. And it's produced by various kinds of cells which includes monocytes, macrophages, fibroblasts, endothelial cells, keratinocytes, mast cells, T-lymphocytes, and also by microglia and astrocytes. Many experimental studies showed that IL6 plays a key role in the pathogenesis of several ischemic cardiovascular disorders, including ischemic stroke ${ }^{[60]}$. TNF- $\alpha$ causes the expression of IL1, IL6 and other cytokines. In the acute phase of ischemia, TNF- $\alpha$ and IL1B are the inflammatory factors which cause the speeds upthe inflammatory lesions, and also causes cell necrosis or $\operatorname{apoptosis}^{[61]}$.

\section{Peripheral Artery Disease}

Peripheral arterial disease (PAD) affects almost 8 million Americans and has more chances to increase its prevalence ${ }^{[62]}$. The disease is related to severe physical impairment and affects the quality of lifestyle ${ }^{[63-65]}$ many other evidences supports a higher risk of mortality in patients with peripheral artery disease ${ }^{[66,67]}$, specifically from cardiovascular causes $^{[68,69]}$. 


\section{Pathogenesis of Pad And Role of Cytokines}

IL-1 enhances the expression of cell adhesion molecules on the endothelial surface and has also been deemed to be proatherogenic $^{[70]}$. The potential role of IL-1 in Peripheral artery disease is IL-6 production, an independent predictor of peripheral artery disease progression. But while IL-1 levels was found to be raised in the pericardial fluid of patients having unstable angina ${ }^{[71]}$, plasma levels of IL-1 weren't found to be indicative of Peripheral artery disease ${ }^{[72,73]}$.

\section{Alcoholic Liver Disease}

Long term increased consumption of alcohol can result in a list of liver abnormalities, likefrom steatosis or steatohepatitis to fibrosis, cirrhosis, and even liver cancer hepatocellular carcinoma. In its mildest form, fatty liver mostly causes no clinically evident symptoms and is very rarely fatal.

\section{Role of Cytokines In Alcoholic Liver Disease}

IL-1 helps in producing inflammatory responses; causes fever; and also stimulates growth and differentiation of immune system cells.Patients with alcoholic liver disease have demonstrated increased serum concentrations of interleukin (IL)-1, tumor necrosis factor- alpha (TNF- $\alpha$ ), IL-6, and IL- $8^{[74]}$.

\section{Inflammatory Bowel Disease}

Inflammatory bowel diseases (IBD) are chronic infections, determined by active and remission periods. The inflammatory bowel diseases is of three forms

- Crohn's Disease (CD),

- Ulcerative Colitis (UC) and

- Indeterminate Colitis.

In inflammatory bowel disease immune tolerance is usually lost by the intestinal flora which is controlled by various substances, especially cytokines.

\section{Pathogenesis and Role Of Il1ß In Ibd (Uc)}

Interleukin 1 (IL-1) in combinationwith TNF- $\alpha$ is vital in the pathogenesis of inflammatory bowel disease becauseof its upregulatory and pro-inflammatory activity. The IL-1 system is subdivided mainly into IL-1 $\alpha$ and IL-1及, both of which causes the production of type 2 cyclo-oxygenase, phospholipase A and inducible nitric oxide synthase (iNOS) ${ }^{[75]}$. The tissular level of IL-1 was found to be predominantlyelevated in UC (Ulcerative colitis) patients ${ }^{[76]}$. The IL-1 system includes antagonists of IL-1 receptors (IL$1 \mathrm{Ra}$ ), as control mechanism. In UC, IL-1, IL-1Ra and the Transforming Growthfactor $\beta 1$ (TGF $\beta 1$ ) which controls the size, time extent of the inflammatory process.

\section{Arthritis}

Arthritis is chronic autoimmune disease which results in inflammation and deformity of joints. It can cause other systemic problems, also cause inflammation of blood vessels, and rheumatic nodules in various body regions ${ }^{[77]}$.

\section{ROLE OF IL-1ß IN ARTHRITIS}

Usually inside joint, the pro-inflammatory cytokines co-exist alongside their endogenous inhibitors. This is a a result of ongoing processes in which pro-inflammatory stimuli induce their anti-inflammatory counterparts and the imbalance between the two causes the disease. The very strong pro- inflammatory cytokines, IL-1 stands out as a paradigmatic example of fine-tuned regulation of biological activities through a complicated system of ligands with agonist and antagonist functions, as well as signaling and non-signaling receptor.

\section{CONCLUSION}

IL-1beta plays a very important role in the pathogenesis of various systemic diseases. Further research in molecular mechanisms of IL-1 pathogenesis can help to modulate in disease prevention in the near future.

\section{References}

1. Brown KD. Zurawski SM. Mosmann TR. Zurawski G. A family of small inducible proteins secreted by leukocytes are members of a new superfamily that includes leukocyte and fibroblast-derived inflammatory agents, growth factors, and indicators of various activation processes. J Immunol. 1989; 142(2):679687. [PubMed]

2. Kim $\mathrm{CH}$. Chemokine-chemokine receptor network in immune cell trafficking. Current Drug Targets. 2004; 4(4):343-361. [PubMed]

3. H. Akiyama, S. Barger, S. Barnum et al., "Inflammation and Alzheimer's disease," Neurobiology of Aging, vol. 21, no. 3, pp. 383-421, 2000.

4. E. E. Tuppo and H. R. Arias, "The role of inflammation in Alzheimer's disease," International Journal of Biochemistry and Cell Biology, vol. 37, no. 2, pp. 289-305, 2005.

5. C. D. Winter, F. Iannotti, A. K. Pringle, C. Trikkas, G. F. Clough, and M. K. Church, "A microdialysis method for the recovery of IL-1 $\beta$, IL-6 and nerve growth factor from human brain in vivo," Journal of Neuroscience Methods, vol. 119, no. 1, pp. 45-50, 2002.

6. M. N. Woodroofe, G. S. Sarna, M. Wadhwa et al., "Detection of interleukin-1 and interleukin-6 in adult rat brain, fol- lowing mechanical injury, by in vivo microdialysis: evidence of a role for microglia in cytokine production," Journal of Neuroimmunology, vol. 33, no. 3, pp. 227-236, 1991.

7. Kiecolt-Glaser JK \& Glaser R: Depression and immune function: central pathways to morbidity and mortality. Journal of psychosomatic research 2002; 53:873-6.

8. Moussavi S et al: Depression, chronic diseases, and decrements in health 2008; 29-32.

9. Dinan TG: Inflammatory markers in depression. Current opinion in psychiatry 2009; 22:32-6.

10. Irwin MR \& Miller AH: Depressive disorders and immunity: 20 years of progress and discovery. Brain, behavior, and immunity 2007; 21:374-83.

11. Raison CL, Capuron L \& Miller AH: Cytokines sing the blues: inflammation and the pathogenesis of depression 2012; 27:24-31.

12. Dantzer $\mathrm{R}$ et al: From inflammation to sickness and depression: when the immune system subjugates the brain. Nature reviews. Neuroscience 2008; 9:46-56.

13. Steiner $\mathrm{J}$ et al: Bridging the gap between the immune and glutamate hypotheses of schizophrenia and major depression: Potential role of glial NMDA receptor modulators and impaired blood-brain barrier integrity. 
The world journal of biological psychiatry: the official journal of the World Federation of Societies of Biological Psychiatry 2012; 13:482-92.

14. Davidson A. Diamond B. Autoimmune diseases. N Engl J Med. 2001; 345(5):340-350. [PubMed]

15. Marrack P. Kappler J. Kotzin BL. Autoimmune disease: why and where it occurs. Nat Med. 2001; 7(8):899-905. [PubMed]

16. Dinarello CA. Immunological and inflammatory functions of the interleukin-1 family. Annu Rev Immunol. 2009; 27:519-550. [PubMed]

17. Johnson VJ. Yucesoy B. Luster MI. Prevention of IL-1 signaling attenuates airway hyperresponsiveness and inflammation in a murine model of toluene diisocyanate-induced asthma. J Allergy ClinImmunol. 2005; 116(4):851-858. [PubMed]

18. Sutton CE. Lalor SJ. Sweeney CM. Brereton CF. Lavelle EC. Mills KH. Interleukin-1 and IL-23 induce innate IL-17 production from gammadelta $\mathrm{T}$ cells, amplifying Th17 responses and autoimmunity. Immunity. 2009; 31(2):331-341. [PubMed]

19. Chung Y. Chang SH. Martinez GJ. Yang XO. Nurieva R. Kang HS. Ma L. Watowich SS. Jetten AM. Tian Q. Critical regulation of early Th17 cell differentiation by interleukin-1 signaling. Immunity. 2009; 30(4):576587. others. [PMC free article] [PubMed]

20. Lee WW. Kang SW. Choi J. Lee SH. Shah K. Eynon EE. Flavell RA. Kang I. Regulating human Th17 cells via differential expression of IL-1 receptor. Blood. 2010; 115(3):530-540. [PMC free article] [PubMed]

21. Ramma W, Ahmed A (2011) Is inflammation the cause of pre-eclampsia? BiochemSoc Trans 39: 1619-1627.

22. ULaMarca BD, Ryan MJ, Gilbert JS, Murphy SR, Granger JP (2007) Inflammatory cytokines in the pathophysiology of hypertension during preeclampsia. CurrHypertens Rep 9: 480-485.

23. Diaz L, Noyola-Martinez N, Barrera D, Hernandez G, Avila E, et al. (2009) Calcitriol inhibits TNF-alphainduced inflammatory cytokines in human trophoblasts. J ReprodImmunol 81: 17-24.

24. Huang SJ, Chen CP, Schatz F, Rahman M, Abrahams VM, et al. (2008) Pre- eclampsia is associated with dendritic cell recruitment into the uterine decidua. $J$ Pathol 214: 328-336.

25. Kalinderis M, Papanikolaou A, Kalinderi K, Ioannidou E, Giannoulis C, et al. (2011) Elevated serum levels of interleukin-6, interleukin-1beta and human chorionic gonadotropin in pre-eclampsia. Am J ReprodImmunol 66: 468-475.

26. Kocyigit Y, Atamer Y, Atamer A, Tuzcu A, Akkus Z (2004) Changes in serum levels of leptin, cytokines and lipoprotein in pre-eclamptic and normotensive pregnant women. GynecolEndocrinol 19: 267-273.

27. Wang J, Huang Y, Huang Y, Zhou J, Liu X (2010) Effect of lipoxin A(4) on IL- 1beta production of monocytes and its possible mechanism in severe preeclampsia. J HuazhongUnivSciTechnolog Med Sci 30: 767-770.

28. Luppi P, Deloia JA (2006) Monocytes of preeclamptic women spontaneously synthesize pro-inflammatory cytokines. ClinImmunol 118: 268-275.

29. Rinehart BK, Terrone DA, Lagoo-Deenadayalan S, Barber WH, Hale EA, et al. (1999) Expression of the placental cytokines tumor necrosis factor alpha, interleukin 1beta, and interleukin 10 is increased in preeclampsia. Am J ObstetGynecol 181: 915-920.

30. American Diabetes Association. Diagnosis and classification of diabetes mellitus. Diabetes Care. 2014; 37 Suppl 1:S81-90. Epub 2013/12/21. doi: 10.2337/dc14-S081 PMID: 24357215.

31. Wellen KE, Hotamisligil GS (2005) Inflammation, stress, and diabetes. J Clin Invest 115:1111-1119.

32. Kolb H, Mandrup-Poulsen T (2005) An immune origin of type 2 diabetes? Diabetologia 48:1038 -1050.

33. Donath MY, et al. (2008) Islet inflammation in type 2 diabetes: From metabolic stress to therapy. Diabetes Care 31:S161-S164.

34. Ehses JA, Perren A, Eppler E, et al. Increased number of islet-associated macrophages in type 2 diabetes. Diabetes 2007;56:2356-2370

35. Richardson SJ, Willcox A, Bone AJ, Foulis AK, Morgan NG. Islet-associated macrophages in type 2 diabetes. Diabetologia 2009;52:1686-1688

36. Maedler K, Sergeev P, Ris F, et al. Glucose-induced beta cell production of IL-1beta contributes to glucotoxicity in human pancreatic islets. J Clin Invest 2002;110:851-860

37. Maedler K, Sergeev $\mathrm{P}$, Ehses JA, et al. Leptin modulates beta cell ex- pression of IL-1 receptor antagonist and release of IL-1beta in human islets. Proc NatlAcadSci USA 2004;101:8138-8143

38. Böni-Schnetzler M, Boller S, Debray S, et al. Free fatty acids induce a proinflammatory response in islets via the abundantly expressed interleukin-1 receptor I. Endocrinology 2009;150:5218-5229

39. Park YJ, Lee S, Kieffer TJ, et al. Deletion of Fas protects islet beta cells from cytotoxic effects of human islet amyloid polypeptide. Diabetologia 2012;55: 1035-1047

40. Park YJ, Woo M, Kieffer TJ, et al. The role of caspase8 in amyloid-induced beta cell death in human and mouse islets. Diabetologia 2014;57:765-775

41. Westwell-Roper CY, Ehses JA, Verchere CB. Resident macrophages mediate islet amyloid polypeptideinduced islet IL-1b production and b-cell dysfunction. Diabetes 2014;63:1698-1711

42. Ware LB, Matthay MA. Medical progress: the acute respiratory distress syndrome. $N$ Engl J Med 2000;342: 1334-1349

43. Goodman R, Pugin J, Lee JS, et al. Cytokine mediated inflammation in acute lung injury. Cytokine Growth Factor Rev 2003;14:523-535

44. Nathan CF. Secretory products of macrophages. J Clin Invest 1987;79:319-326

45. Miller EJ, Cohen AB, Matthay MA. Increased interleukin- 8 concentrations in the pulmonary edema fluid of patients with acute respiratory distress syndrome from sepsis. Crit Care Med 1996;24:14481454

46. Fan J, Ye RD, Malik AB. Transcriptional mechanisms in acute lung injury. Am J Physiol Lung Cell Mol Physiol 2001;281:L1037-L50

47. Christman JW, Sadikot RT, Blackwell T. The role of nuclear factor-k B in pulmonary diseases. Chest 2000;117: 1482-1487 
48. Murtaugh M.P., Baarsch M.J., Zhou Y., Scamurra R.W., Lin G., Inflammatory cytokines in animal health and disease, Vet. Immunol. Immunopathol. 54 (1996) 45-55.

49. Cohen J., The immunopathogenesis of sep- sis, Nature 420 (2002) 885-891.

50. Bonfield TL, Konstan MW, Burfeind P, Panuska JR, Hilliard JB, Berger M. Normal bronchial epithelial cells constitutively produce the anti-inflammatory cytokine interleukin-10, which is downregulated in cystic fibrosis. Am J Respir Cell Mol Biol 1995; 13: 257-61.

51. Fiorentino DF, Zlotnik A, Mosmann TR, Howard M, O'Garra A. IL10 inhibits cytokine production by activated macrophages. J Immunol 1991; 147:3815-22.

52. Bogdan C, Vodovotz Y, Nathan C. Macrophage deactivation by interleukin 10. J Exp Med 1991; 174:1549-55.

53. Kronborg G, Hansen MB, Svenson M, Fomsgaard A, Hoiby N, Bendtzen K. Cytokines in sputum and serum from patients with $\mathrm{CF}$ and chronic Pseudomonas aeruginosa infection as markers of destructive inflammation in the lungs. Pediatr Pulmonol 1993; 15: 292-7.

54. Aris RM, Stephens AR, Ontjes DA, Denene Blackwood A, Lark RK, Hensler MB, et al. Adverse alterations in bone metabolism are associated with lung infection in adults with CF. Am J Crit Care Med 2000;162:1674-8.

55. Feigin VL, Forouzanfar MH, Krishnamurthi R, Mensah GA, Connor M, Bennett DA, Moran AE, Sacco RL, Anderson L, Truelsen T, O'Donnell M, Venketasubramanian N, Barker-Collo S, Lawes CMM, Wang W, Shinohara Y, Witt E, Ezzati M, Naghavi M, Murray C. 2014. Global and regional burden of stroke during 1990-2010: findings from the Global Burden of Disease Study 2010. The Lancet 383:245-255 DOI 10.1016/S0140-6736(13)61953-4.

56. Dinarello CA, Simon A, Van der Meer JW. 2012. Treating inflammation by blocking interleukin-1 in a broad spectrum of diseases. Nature Reviews Drug Discovery 11:633-652 DOI 10.1038/nrd3800.

57. Kostulas N, Pelidou SH, Kivisakk P, Kostulas V, Link H. 1999. Increased IL-1beta, IL-8, and IL-17 mRNA expression in blood mononuclear cells observed in a prospective ischemic stroke study. Stroke 30:21742179 DOI 10.1161/01.STR.30.10.2174.

58. Ferrarese C, Mascarucci P, Zoia C, Cavarretta R, Frigo M, Begni B, Sarinella F, Frattola L. 1999. Increased cytokine release from peripheral blood cells after acute stroke. Journal of Cerebral Blood Flow and Metabolism 19:1004-1009 DOI 10.1097/00004647199909000-00008.

59. Ridker PM, Rifai N, Stampfer MJ, Hennekens CH. 2000. Plasma concentration of interleukin- 6 and the risk of future myocardial infarction among apparently healthy men. Circulation 101:1767-1772 DOI 10.1161/01.CIR.101.15.1767.

60. Quan Z, Quan Y, Wei B, Fang D, Yu W, Jia H, Quan W, Liu Y, Wang Q. 2015. Protein- protein interaction network and mechanism analysis in ischemic stroke. Molecular Medicine Reports 11:29-36 DOI 10.3892/mmr.2014.2696.
61. Kawai C. 1999. From myocarditis to cardiomyopathy: mechanisms of inflammation and cell death: learning from the past for the future. Circulation 99:1091-1100 DOI 10.1161/01.CIR.99.8.1091.

62. Allison MA, Ho E, Denenberg JO, Langer RD, Newman AB, Fabsitz RR, et al. Ethnic-specific prevalence of peripheral arterial disease in the United States. Am J Prev Med. 2007; 32(4):328-33.

63. McDermott MM, Greenland P, Liu K, Guralnik JM, Celic L, Criqui $\mathrm{MH}$, et al. The ankle brachial index is associated with leg function and physical activity: the Walking and Leg Circulation Study. Ann Intern Med. 2002; 136(12):873-83.

64. McDermott MM, Liu K, Greenland P, Guralnik JM, Criqui $\mathrm{MH}$, Chan $\mathrm{C}$, et al. Functional decline in peripheral arterial disease: associations with the ankle brachial index and leg symptoms. JAMA. 2004; 292(4):453-61.

65. McDermott MM, Guralnik JM, Tian L, Liu K, Ferrucci $\mathrm{L}$, Liao $\mathrm{Y}$, et al. Associations of borderline and low normal ankle-brachial index values with functional decline at 5-year follow-up: the WALCS (Walking and Leg Circulation Study). J Am Coll Cardiol. 2009; 53(12):1056-62.

66. Diehm C, Lange S, Darius H, Pittrow D, von Stritzky B, Tepohl G, et al. Association of low ankle brachial index with high mortality in primary care. Eur Heart $J$. 2006; 27(14):1743-9.

67. Ankle Brachial Index C, Fowkes FG, Murray GD, Butcher I, Heald CL, Lee RJ, et al. Ankle brachial index combined with Framingham Risk Score to predict cardiovascular events and mortality: a metaanalysis. JAMA. 2008; 300(2):197-208.

68. Resnick HE, Lindsay RS, McDermott MM, Devereux RB, Jones KL, Fabsitz RR, et al. Relationship of high and low ankle brachial index to all-cause andcardiovascular disease mortality: the Strong Heart Study. Circulation. 2004; 109(6):733-9.

69. Heald CL, Fowkes FG, Murray GD, Price JF. Ankle Brachial Index C: Risk of mortality and cardiovascular disease associated with the ankle-brachial index: Systematic review. Atherosclerosis. 2006; 189(1):61-9.

70. Mackay C. R. (2001) Chemokines: immunology's high impact factors. Nat. Immunol. 2:95-101.

71. Bhagat K., Vallance P. (1997) Inflammatory cytokines impair endothelium-dependent dilatation in human veins in vivo. Circulation 96:3042-3047.

72. Dinarello CA. IL-18: A TH1-inducing, proinflammatory cytokine and new member of the IL-1 family. J Allergy ClinImmunol 1999; 103(1 Pt 1): 1124.

73. Oyama J, Shimokawa H, Morita S, Yasui H, Takeshita A. Elevated interleukin-1beta in pericardial fluid of patients with ischemic heart disease. Coron Artery Dis 2001; 12: 567-71.

74. Fiotti N, Giansante C, Ponte E et al. Atherosclerosis and inflammation. Patterns of cytokine regulation in patients with peripheral arterial disease. Atherosclerosis 1999; 145: 51-60.

75. DINARELLO CA. The IL-1 family and inflammatory diseases. Clinical and experimental rheumatology. 2002; 20 (5 Suppl 27):S1-13. 
76. Ashwood P, Harvey R, Verjee T, Wolstencroft R, Thompson Rp, Powell JJ. Functional interactions between mucosal IL-1, IL-ra and TGF-beta 1 in ulcerative colitis. Inflammation research: official Journal of the European Histamine Research Society [et al]. 2004; 53(2):53-9.
77. Wong JB, Ramey DR, Singh G (2001) Long-term morbidity, mortality, and economics of rheumatoid arthritis. Arthritis Rheum, 44, 2746-9.

\section{How to cite this article:}

Valli B and M.Sankari (2017) ' Role Of Cytokines In Inflammatory Diseases', International Journal of Current Advanced Research, 06(05), pp. 3645-3651.

DOI: http://dx.doi.org/10.24327/ijcar.2017.3651.0338 